\title{
Quality evaluation of macaroons added with moringa leaf (Moringa oleifera Lam.) and green tea powder
}

\author{
Chae-Wan Baek, Jeung-Hee Lee* \\ Department of Food and Nutrition, Daegu University, Gyeongsan 38453, Korea
}

\section{모링가잎과 녹차 분말을 첨가한 마카롱의 품질 평가}

\author{
백채완 - 이정희* \\ 대구대학교 식품영양학과
}

\begin{abstract}
The quality characteristics and antioxidant activities of macaroons added with $5 \%$ and $7.5 \%$ of moringa leaf and green tea powder were evaluated. Moringa macaroons were more bright and yellow-reddish than green tea macaroons that showed a strong green color. The spread factor of macaroons decreased significantly with the increasing powder content. The fracturability and cohesiveness increased in the macaroons added with powder whereas the hardness decreased. The total phenolics (TPC) and total flavonoid contents (TFC) of macaroons with green tea were significantly higher than those of macaroons with moringa, resulting in higher DPPH radical scavenging capacity and feric reducing antioxidant power $(\mathbf{p}<0.05)$; these values increased with increasing moringa leaf or green tea powder content $(p<0.05)$. Antioxidant activity has a higher correlation with TFC than TPC. The sensory intensities of greenness, grass flavor, green taste and chewiness were higher in macaroons with green tea than in macaroon with moringa. The sensory taste, aroma, and texture properties were better, and the overall acceptability was higher in macaroons added with green tea than that with moringa. In this study, green tea was found to be an excellent ingredient for manufacture of macaroons with sensory preference as functional dessert bakery products with high antioxidant power.
\end{abstract}

Key words : Moringa oleifera Lam, green tea, macaroon, quality characteristics, antioxidant activity

서 론

모링가(Moringa oleifera Lam.)는 모링가과(Moringaceae) 의 낙엽교목으로 인도가 원산지이며, 필리핀, 싱가포르, 자메 이카 등에서 재배되고 있다(Ramachandran 등, 1980). 모링가 는 생긴 모양으로 인해 'drumstick', 'horse radish'으로, 또는 다양한 영양소와 생체 활성 물질이 풍부하여 'Mother's best friend'라 불리며, 특히 단백질이 풍부하여 영양부족 세계 인 구를 위한 단백질-열량 영양실조의 해결에 도움이 될 수 있다 고 알려져 있다(Singh과 Prasad, 2013). 모링가잎은 flavonoid, ascorbic acid, carotenoid, polyphenol 등의 항산화물질이 풍 부하고(Saini 등, 2014; Siddhuraju와 Becker, 2003), 항염증, 항당뇨, 항혈관 신생작용 효과가 알려져 있다(Kumar 등, 2013). 차나무(Camellia sinensis)의 싹이나 잎을 가공하여 얻 어진 녹차는 비타민, 무기질 등이 풍부하고, 건강증진효과뿐 만 아니라, 맛과 향 등의 기호도가 우수하여 가장 즐겨 마시 는 차 중 하나이다(Im과 Kim, 1999). 녹차는 catechin으로 알 려진 flavonol류를 포함한 polyphenol을 다량 함유하고 있어, 천연 산화방지제로 이용되고(Jaiswal와 Naik, 2017; Nadiah 등, 2015), 녹차의 카테킨은 혈중 콜레스테롤을 감소시킴으

*Corresponding author. E-mail : jeunghlee@daegu.ac.kr, Phone :+82-53-850-6836, Fax : +82-53-850-6839

Received 20 April 2020; Revised 19 May 2020; Accepted 19 May 2020.

Copyright (c) The Korean Society of Food Preservation.

This is an Open Access article distributed under the terms of the Creative Commons Attribution Non-Commercial License (http://creativecommons.org/licenses/by-nc/4.0) which permits unrestricted non-commercial use, distribution, and reproduction in any medium, provided the original work is properly cited. 
로써 동맥경화예방 효과가 있으며, 체중 증가 억제 효과가 보 고되어 있다(Muramatsu 등 1986). 최근 소득 수준 향상 및 산업의 발달로 인하여 삶의 질은 향상되었으나, 다양한 스트 레스와 환경오염에 노출되면서 건강에 대한 욕구는 지속적으 로 증가되어, 건강에 대한 소비자들의 관심표현인 웰빙과 관 련된 소비행동의 변화와 건강 관련 사업의 증가를 가져오게 되었다(Baek과 Jeong, 2006).

현대인들은 정서 완화 및 행복감 증진 등을 기대하며 디저 트 상품을 구매하며, 소비자들은 일반제품의 구매에 있어서 가성비 위주의 소비 경향을 보이지만, 디저트 상품의 소비에 서만큼은 가심비 위주의 지출을 하는 경향이 있다 $(\mathrm{Yu}$ 와 $\mathrm{Ahn}, 2018)$. 가심비란 자신의 마음의 만족감을 채우는 것을 중시하여 이를 위한 지출을 아끼지 않는 것으로, 식품업계는 이러한 추세에 따라 가심비 마케팅을 지향하고 있다 $(\mathrm{Yu}$ 등, 2018). 특히 베이커리 시장은 제품 고급화 등의 변화에 따라 프리미엄 디저트가 인기를 끌고 있고, 소매시장의 경우, 2014 년 3,781억 원에서 2016년 4,060억 원으로 3년간 약 $7.4 \%$ 증가하였다(AT FIS, 2017). 디저트 제품 중 마카롱은 다양한 색감과 필링으로 시각을 자극하며, 소비자들의 social network service를 통한 인증이 지속되면서 이로 인한 소비증 가 추세를 보이고 있다. 마카롱은 이탈리아에서 처음 시작된 프티 푸르세크(Petit four sec) 과자 중 하나로 아몬드가루로 만드는 것이 특징이며, 설탕과 달걀흰자가 첨가되어 고소한 맛과 부드러운 조직감을 갖지만, 다른 제품들에 비해 제조과 정이 까다로워 고가의 디저트로 판매되고 있다(Park 등, 2018). 최근 일부 마카롱 제품에서 황색포도상구균이 검출되고, 타르색소가 기준치 이상 함유하면서(Korea Consumer Agency, 2019), 인공색소 사용에 따른 안전성 문제들이 제기되고, 이 에 따라 기능적으로 우수한 성분이 함유된 천연재료를 사용 한 디저트 연구가 활발히 진행되고 있다(Park 등, 2018).

모링가와 녹차를 기능성 베이커리 제품의 소재로 활용한 여러 연구들을 살펴보면, 모링가잎 분말을 첨가한 쿠키와 머 핀은 총페놀 함량과 DPPH radical 소거능이 높아 항산화 활 성이 우수하고, 알코올 분해 활성이 높았으며, 쿠키는 $5 \%$ 수 준, 머핀은 $3 \%$ 수준의 첨가량이 기호도 증가 및 관능적 특성 에 긍정적 영향을 준다고 보고하였다(Choi, 2018; Jung, 2016). 녹차 분말을 첨가한 쌀스펀지 케이크에서는 총페놀 및 플라 보노이드 함량이 증가하였고, 이에 비례하여 DPPH와 ABTS radical 소거활성이 증가하였으며, 녹차 첨가 쌀스펀지케이크 와 식방은 각각 $3 \%, 1 \%$ 첨가군에서 전체적인 기호도가 가장 좋게 나타났다(Lee와 Hwang, 2016; Park과 Lee, 1999). 선행 연구들에서 모링가잎 분말과 녹차의 첨가량이 증가할수록 항 산화 활성은 증가하였지만, 첨가량이 일정 수준보다 높을 경 우, 모링가와 녹차 특유의 향과 맛에 의해 관능적 특성의 기 호도에서 차이를 보였다.
본 연구에서는 모링가잎과 녹차 분말이 첨가된 디저트인 마카롱을 제조하여, 제품의 품질과 관능적 특성 및 항산화 활 성을 조사하였다. 이를 바탕으로 베이커리 제품에서의 모링 가와 녹차의 활용도를 증가시키고, 건강 지향적이고 관능적 특성이 우수한 디저트 제품의 소재로서 활용되기 위한 기초 자료를 제공하고자 한다.

\section{재료 및 방법}

\section{실험재료 및 시약}

아몬드가루(Woosin Food Co., Ltd., Icheon, Korea), 슈거 파우더(Kkomida Co., Ltd., Icheon, Korea), 모링가 분말 (Grenera nutrients Pvt., Ltd., Erode, Tamil Nadu, India), 가 루 녹차(Nokchawon Co., Ltd., Seoul, Korea), 설탕(CJ CheilJedang Co., Ltd., Incheon, Korea), 버터(Seoul Milk, Yongin, Korea), 달걀은 시중에서 구입하여 사용하였다. 모 링가분말과 녹차분말의 입자는 균일하지 않아 체에 내린 후 사용하였다. 2,2-Diphenyl-1-picrylhydrazyl (DPPH), Folin \& Ciocalteu's phenol reagent, gallic acid, sodium nitrite $\left(\mathrm{NaNO}_{2}\right)$. quercetin, Iron(III) choride hexahydrate $\left(\mathrm{FeCl}_{3}\right), 2,4,6$-tri(2pyridy1)-s-triazine(TPTZ)는 Sigma-Aldrich Co. Ltd.(St. Louis, $\mathrm{MO}, \mathrm{USA})$ 에서, sodium carbonate $\left(\mathrm{Na}_{2} \mathrm{CO}_{3}\right)$ 는 Junsei chemical Co., Ltd(Tokyo, Japan)에서 구입하였고, L(+)-asocrbic acid 와 sodium acetate trihydratel은 Samchun Pure Chemical Co., Ltd.(Pyeongtaek, Korea)의 제품을 사용하였다.

\section{분말의 수분함량 및 수분흡수지수 측정}

모링가분말, 녹차분말, 아몬드가루의 수분함량은 $\mathrm{AOAC}$ 법(AOAC, 1990)으로 각각 3 회 반복 측정하였다. 모링가와 녹차 분말의 수분흡수지수(water absorption index, WAI)는 시료 $1 \mathrm{~g}$ 을 증류수 $20 \mathrm{~mL}$ 와 혼합하고, $25^{\circ} \mathrm{C}, 130 \mathrm{rpm}$ 의 shaking water bath(Daihan labtech Co., Namyangju, Korea) 에서 20 분간 교반하고 10 분간 원심분리 $(2,000 \times g)$ 하였다. 상층액은 제거하고 침전물의 무게를 측정한 후, 시료 $\mathrm{g}$ 당 흡 수된 수분함량으로 표시하였다.

$$
\text { WAI }=\frac{\text { Hydrated sample weight }- \text { Dry sample weight }}{\text { Dry sample weight }}
$$

\section{마카롱 제조}

아몬드가루 대비 모링가잎 또는 녹차 분말의 첨가비율은 예비실험을 통해 맛과 향이 좋고, 전체적인 기호도가 높은 $5 \%$ 와 $7.5 \%$ 으로 선정하고, Table 1에 의거하여 마카롱을 제 조하였다. Tant-Pour-Tant(T.P.T., 마카롱 껍질 반죽) 재료를 
계량하여 체에 내린 후, 달걀흰자와 섞어 반죽을 준비하고, 설탕과 물을 혼합하고 $118^{\circ} \mathrm{C}$ 까지 온도를 올려 설탕 시럽을 만 들었다. 달걀흰자를 핸드믹서(DH-200, Guangdong Xinbao Electrical Appliances Holdings Co., Ltd., Foshan, China)를 이용해 고속에서 1 분간 휘핑하고, 앞서 제조한 설탕 시럽을 휘핑한 흰자에 천천히 부어가며 고속 3 분, 중속 2 분, 저속 1 분 회전시켜 머랭을 제조하였다. 완성된 머랭은 미리 반죽해 둔 T.P.T.에 2회 정도 나누어 섞어주면서 덩어리가 발생하지 않고, 적당한 반죽 되기가 되도록 작업하였다. 완성된 마카롱 반죽은 짤주머니에 넣어 일정한 무게 $(8 \mathrm{~g})$ 로 짠 뒤, 실온에서 건조시켜, 윗불 $140^{\circ} \mathrm{C}$, 아랫불 $150^{\circ} \mathrm{C}$ 의 오븐에서 16 분간 구 운 후 1 시간 정도 식힌 뒤 마카롱 꼬끄에 필링으로 버터 크림 $(5 \mathrm{~g})$ 을 채워 마카롱을 완성하였다.

\section{마카롱의 부피 및 퍼짐성 지수 측정}

마카롱 꼬끄의 부피는 종자치환법으로 3 회 반복 측정하여 평균값으로 나타내었다. 마카롱 꼬끄의 퍼짐성 지수는 $\mathrm{AACC}$ Method 10-50D의 방법(AACC, 1983)으로 측정하였다. 마카 롱 꼬끄 6개를 가로로 정렬하여 그 길이를 측정하고, 각각의 마카롱 꼬끄를 $90^{\circ}$ 로 회전시켜 다시 측정하여 얻은 수치를 각각 6 으로 나누어서 평균 직경 $(\mathrm{mm})$ 을 구하였다. 평균 두께 $(\mathrm{mm})$ 는 6개의 마카롱 꼬끄를 세로로 쌍아 올려 높이를 측정 한 후, 다시 쌓아 올린 순서를 바꾸어 높이를 측정하여 얻은 수치를 각각 6 으로 나누어 구한 후 아래의 식을 이용하여 퍼 짐성지수를 계산하였다.

Spread factor of coque $=$

$$
\frac{\text { 마카롱 6개에 대한 평균 직경 }(\mathrm{mm})}{\text { 마카롱 6개에 대한 평균 두께 }(\mathrm{mm})}
$$

\section{마카롱의 텍스쳐 측정}

Rheometer(Compac 100, Sun Scientific, Tokyo, Japan)를
이용하여 texture profile analysis (TPA) 방법으로 깨짐성 (fracturability), 응집성(cohesiveness), 및 경도(hardness)를 측정하였다. 측정 조건은 진입 거리 $30 \%$, 테이블 속도 120 $\mathrm{mm} / \mathrm{min}$, 최대 응력 $10 \mathrm{~kg}$, 시료와 어댑터 거리 $5.00 \mathrm{~mm}$, 시 료 지름 $4.5 \mathrm{~cm}$ 로 설정하였으며, No.14 probe $(\$ 10 \mathrm{~mm})$ 를 사 용하였다.

\section{마카롱의 색도 측정}

분말과 마카롱의 색도는 색차계(Chroma meter CR-300, Minolta, Tokyo, Japan)를 사용하여 Hunter L값(lightness), a 값(+red/-green), b값(+yellow/-blue)을 각각 5 회 또는 3 회 반 복 측정하여 평균값을 구하였다. Standard plate의 $\mathrm{L}, \mathrm{a}, \mathrm{b}$ 값 은 각각 $97.75,-0.48,2.07$ 이고, 마카롱의 전반적 색도 차이 $(\Delta \mathrm{E})$ 는 $\sqrt{\Delta E L^{2}+\Delta a^{2}+\Delta b^{2}}$ 으로 구하였다.

\section{관능검사}

모링가잎 또는 녹차 분말의 첨가수준에 따른 마카롱의 관능 적 특성 차이를 조사하기 위하여 식품영양학과 학생 47명을 대상으로 평가항목에 대한 특성을 설명하고, 관능평가방법을 훈련시킨 후 관능검사를 실시하였다(IRB 승인번호: 1040621201909-HR-019-08). 마카롱은 제조 후 냉장고에서 24시간 숙성시킨 후 제공하였다. 마카롱의 관능적 특성 강도는 녹색 (greenish color), 풋내(grass smell), 풋맛(green taste), 단맛 (sweetness), 쫀득함(chewiness)의 강한 정도를 7점척도법(1 점-매우 약하다, 4점-보통이다, 7점-매우 강하다)으로 평가하 였다. 마카롱의 기호도는 외관(appearance), 색(color), 향 (aroma), 맛(taste), 조직감(texture), 전체적인 기호도(overall acceptability)를 7점척도법(1점-매우 싫다, 4점-보통이다, 7 점-매우 좋다)으로 평가하였다. 관능검사 결과는 Duncan's multiple range test를 이용하여 각 시료군 간의 유의적인 차 이를 검증하였다 $(\mathrm{p}<0.05)$.

Table 1. Recipes of macaroon added with moringa leaf powder or green tea powder

(unit: g)

\begin{tabular}{|c|c|c|c|c|c|c|c|c|c|c|}
\hline \multirow[b]{2}{*}{ Macaroor } & & \multicolumn{5}{|c|}{ Tant Pour Tant (T.P.T) } & \multicolumn{3}{|c|}{ Meringue } & \multirow[b]{2}{*}{ Total } \\
\hline & & $\begin{array}{l}\text { Almond } \\
\text { powder }\end{array}$ & $\begin{array}{c}\text { Sugar } \\
\text { powder }\end{array}$ & $\begin{array}{c}\text { Egg } \\
\text { white }\end{array}$ & $\begin{array}{l}\text { Moringa } \\
\text { leaf } \\
\text { powder }\end{array}$ & $\begin{array}{c}\text { Green tea } \\
\text { powder }\end{array}$ & Egg white & Sugar & Water & \\
\hline Control & & 100 & 100 & 36 & - & - & 36 & 100 & 25 & 397 \\
\hline \multirow{2}{*}{ Moringa leaf } & $5 \%$ & 95 & 100 & 36 & 5 & - & 36 & 100 & 25 & 397 \\
\hline & $7.5 \%$ & 92.5 & 100 & 36 & 7.5 & - & 36 & 100 & 25 & 397 \\
\hline \multirow{2}{*}{ Green tea } & $5 \%$ & 95 & 100 & 36 & - & 5 & 36 & 100 & 25 & 397 \\
\hline & $7.5 \%$ & 92.5 & 100 & 36 & - & 7.5 & 36 & 100 & 25 & 397 \\
\hline
\end{tabular}




\section{마카롱의 총페놀 및 총플라보노이드 함량 측정}

마카롱 꼬끄를 막자사발에서 분쇄한 후 $500 \mathrm{mg}$ 취하여 $80 \%$ ethanol $10 \mathrm{~mL}$ 와 혼합하고, water bath $\left(55^{\circ} \mathrm{C}, 125 \mathrm{rpm}\right)$ 에서 1시간, ultrasonication(JAC-2010, KODO Technial Research Co., Ltd., Hwaseog, Korea)에서 1시간 더 추출한 후 원심분리 $(2,000 \times g, 10$ 분 $)$ 하였다. 얻은 상층액을 sodium sulfate column을 통과시켜 수분을 제거하고, 질소 $\left(\mathrm{N}_{2}\right)$ 으로 농축하여 용매를 완전히 제거한 후 $80 \%$ ethanol $2 \mathrm{~mL}$ 에 재 용해한 후 각종 분석에 사용하였다.

마카롱꼬끄의 총페놀 화합물 함량은 Folin Denis's phenol method으로 측정하였다. Test tube에 4배 희석된 시료추출액 $250 \mu \mathrm{L}$, 증류수 $2,250 \mu \mathrm{L}$, Folin-Ciocalteu reagent $250 \mu \mathrm{L}$ 를 넣어 혼합하고 3 분간 방치한 후, $1 \mathrm{~N} \mathrm{Na}_{2} \mathrm{CO}_{3} 500 \mu \mathrm{L}$ 를 첨가 하고 암소에서 1 시간 동안 반응시켰다. 그 후 Syringe filter $(0.22 \mu \mathrm{m}, 13 \mathrm{~mm})$ 로 여과한 다음, spectrophotometer (Thermo Scientific Evolution 201 Series, Thermo Scientific Inc., Waltham, MA, USA)를 사용하여 $725 \mathrm{~nm}$ 에서 흡광도 를 측정하였다. Gallic acid를 표준물질로 사용하여 검량선을 작성하고, 총페놀 함량은 $\mathrm{mg}$ gallic acid equivalent(mg $\mathrm{GAE} / \mathrm{g}$ macaroon)으로 나타내었다. 마카롱꼬끄의 총플라보 노이드 함량은 Abdel-hameed(2009)의 방법을 응용하여 측정 하였다. 2 배 희석한 시료추출액 $250 \mu \mathrm{L}$ 에 증류수 $1 \mathrm{~mL}$ 를 가 하여 5 분간 방치하고, $5 \% \mathrm{NaNO}_{2}$ 와 $10 \% \mathrm{AlCl}_{3}$ 를 각각 75 $\mu \mathrm{L}$ 씩 첨가하여 교반한 뒤 6 분간 반응시켰다. 그 후 $1 \mathrm{M}$ $\mathrm{NaOH} 500 \mu \mathrm{L}$ 와 증류수 $600 \mu \mathrm{L}$ 를 첨가하고 Syringe filter 로 여과한 후 $510 \mathrm{~nm}$ 에서 흡광도를 측정하였다. 표준물질 로는 quercetin을 사용하여 검량선을 작성하고, 총플라보노 이드 함량은 $\mathrm{mg}$ quercetin equivalent(mg QE/g macaroon) 으로 나타내었다. 실험결과는 4회 반복하여 평균과 표준편 차로 나타내었다.

\section{마카롱의 항산화 활성 측정}

마카롱 꼬끄의 항산화 활성은 2,2-diphenyl-1-picrylhydrazyl (DPPH) free radical scavenging capacity(RSC)와 ferric reducing antioxidant power(FRAP)에 의한 환원력을 측정하 여 평가하였다. DPPH 라디칼 소거능은 시료 추출액 $100 \mu \mathrm{L}$, ethanol $900 \mu \mathrm{L}, 0.15 \mathrm{mM}$ DPPH solution $1,250 \mu \mathrm{L}$ 를 혼합 하고, 암소에서 30 분간 방치한 뒤, Syringe filter로 여과하고 $517 \mathrm{~nm}$ 에서 흡광도를 측정하였다. DPPH RSC(\%)을 아래 의 식을 이용하여 구하고, 4 회 반복 측정한 값들의 평균과 표준편차로 나타내었다.

DPPH free radical scavenging capacity $(\%)=$

$$
\frac{\mathrm{Abs}_{\text {blank }}-\mathrm{Abs}_{\text {sample }}}{\mathrm{Abs}_{\text {blank }}} \times 100
$$

FRAP는 Benzie와 Strain의 방법(Benzie와 Strain, 1996)을 변형하여 측정하였다. $300 \mathrm{mM}$ acetate buffer(pH 3.6), 10 $\mathrm{mM}$ TPTZ in $40 \mathrm{mM} \mathrm{HCl}, 20 \mathrm{mM} \mathrm{FeCl} \cdot 6 \mathrm{H}_{2} \mathrm{O}$ 를 $10: 1: 1$ $(\mathrm{v} / \mathrm{v} / \mathrm{v})$ 의 비율로 혼합하여 FRAP reagent를 만들어 사용하였 다. 10 배 희석한 시료추출액 $150 \mu \mathrm{L}$ 와 FRAP reagent $4.5 \mathrm{~mL}$ 를 혼합한 뒤 $37^{\circ} \mathrm{C}$ 의 water bath에서 4 분간 반응시키고, 593 $\mathrm{nm}$ 에서 흡광도를 측정하였다. 표준물질로는 ascorbic acid를 사용하여 검량선을 작성하고, FRAP value는 $\mathrm{mg}$ ascorbic acid equivalent(mg AAE/g macaroon)로 나타내었다. 실험결 과는 4 회 반복 측정한 값들의 평균과 표준편차로 나타내었다.

\section{통계처리}

실험결과는 SAS 9.4(Statistical Analysis System, SAS Institute Inc., Cary, NC, USA)을 이용하여 분산분석(Analysis of variance: ANOVA)을 실시하고, Duncan's multiple range test으로 각 시료군들간의 유의적인 차이를 $\mathrm{p}<0.05$ 수준에서 검정하였다. 총페놀과 총플라보이드 함량과 항산화 활성간의 상관관계는 SPSS 통계프로그램(25, IBM Corp., Armonk, $\mathrm{NY}, \mathrm{USA}$ )의 상관관계분석(correlation analysis)을 실시하여 Pearson correlation coefficient(r)와 유의확률(p-value)를 구 하고, $\alpha=0.05$ 또는 $\alpha=0.01$ 의 유의수준에서 검정하였다.

\section{결과 및 고찰}

\section{마카롱의 색도와 외관}

모링가와 녹차 분말을 첨가한 마카롱의 색도와 외관 사진 은 Table 2 및 Fig. 1과 같다. 명도를 나타내는 L(lightness)값 은 대조군 마카롱(아몬드분말 $100 \%$ )에서 가장 높고, 모링가 와 녹차 분말 첨가량이 증가할수록 L값은 감소하였으며, 모 링가 첨가군이 녹차 첨가군보다 높은 경향을 띄었다. 적색도 를 나타내는 a(redness)값은 모링가 5\% 첨가 마카롱이 가장 높고 $(\mathrm{p}<0.05)$, 녹색도(greenness)는 분말 첨가량이 증가할수 록 높은 경향을 보였으며, 녹차 첨가군이 모링가 첨가군보다 유의적으로 높게 나타났는데 $(\mathrm{p}<0.05)$, 이는 마카롱 외관 사 진 결과와 동일하였다. 황색도(yellowness)를 나타내는 b값은 대조군 마카롱이 가장 낮고, 모링가 첨가군이 녹차 첨가군보 다 유의적으로 높은 황색도를 나타내었으나 $(\mathrm{p}<0.05)$, 분말 첨가량의 증가에 따른 차이는 없었다 $(\mathrm{p}>0.05)$. 마카롱의 외 관은 색도 결과와 유사하게, 대조군 마카롱이 가장 밝고, 녹 차 첨가 마카롱은 녹색이 강하고, 모링가 첨가 마카롱은 황색 과 적색이 강함을 육안으로도 관찰할 수 있었다(Fig. 1). 마카 롱의 주재료인 아몬드와 부재료인 모링가와 녹차 분말의 색 도 측정 결과, $\mathrm{L}$ 값과 $\mathrm{a}$ 값은 아몬드 > 녹차 > 모링가 분말 순 으로, $b$ 값은 모링가 > 녹차 > 아몬드 분말 순이었으며(Table 
Table 2. The Hunter's color value of powders and macaroon added with moringa leaf and green tea powder

\begin{tabular}{|c|c|c|c|c|c|c|}
\hline & Color value & Almond powder & \multicolumn{2}{|c|}{ Moringa leaf powder } & \multicolumn{2}{|c|}{ Green tea powder } \\
\hline \multirow{5}{*}{ Powder } & $\mathrm{L}$ & $82.35 \pm 0.48^{1) \mathrm{a} 2)}$ & \multicolumn{2}{|c|}{$61.39 \pm 0.58^{\mathrm{c}}$} & \multicolumn{2}{|c|}{$64.49 \pm 1.77^{\mathrm{b}}$} \\
\hline & $\mathrm{a}$ & $-1.58 \pm 0.12^{\mathrm{a}}$ & & & -6 & $17^{\mathrm{b}}$ \\
\hline & $\mathrm{b}$ & $19.68 \pm 0.38^{\mathrm{c}}$ & 30 & & 28. & $46^{\mathrm{b}}$ \\
\hline & \multirow{2}{*}{ Color value } & \multirow{2}{*}{ Control } & \multicolumn{2}{|c|}{ Moringa leaf powder } & \multicolumn{2}{|c|}{ Green tea powder } \\
\hline & & & $5 \%$ & $7.5 \%$ & $5 \%$ & $7.5 \%$ \\
\hline \multirow{4}{*}{ Macaroon } & $\mathrm{L}$ & $84.89 \pm 0.60^{\mathrm{a}}$ & $66.16 \pm 0.25^{\mathrm{b}}$ & $61.28 \pm 0.21^{\mathrm{c}}$ & $61.58 \pm 0.58^{\mathrm{c}}$ & $61.08 \pm 0.30^{\mathrm{c}}$ \\
\hline & a & $-1.10 \pm 0.04^{\mathrm{b}}$ & $2.05 \pm 0.18^{\mathrm{a}}$ & $-1.04 \pm 0.16^{\mathrm{b}}$ & $-3.64 \pm 0.05^{\mathrm{c}}$ & $-3.83 \pm 0.00^{\mathrm{c}}$ \\
\hline & $\mathrm{b}$ & $9.23 \pm 0.26^{\mathrm{c}}$ & $22.16 \pm 0.30^{\mathrm{a}}$ & $22.98 \pm 0.34^{\mathrm{a}}$ & $19.91 \pm 0.17^{\mathrm{b}}$ & $19.76 \pm 1.13^{b}$ \\
\hline & $\Delta \mathrm{E}$ & - & $23.01 \pm 1.04^{\mathrm{d}}$ & $27.36 \pm 1.09^{\mathrm{a}}$ & $25.79 \pm 1.11^{\mathrm{b}}$ & $24.25 \pm 1.75^{\mathrm{c}}$ \\
\hline
\end{tabular}

${ }^{1)}$ Each powder value is mean $\pm \mathrm{SD}(\mathrm{n}=5)$, Each Macaroon value is mean $\pm \mathrm{SD}(\mathrm{n}=3)$.

${ }^{2)}$ Values with different superscripts within the same row are significantly different at $\mathrm{p}<0.05$.

(A)

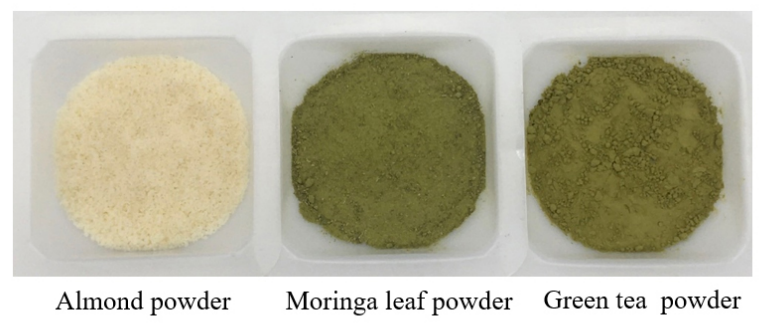

(B)

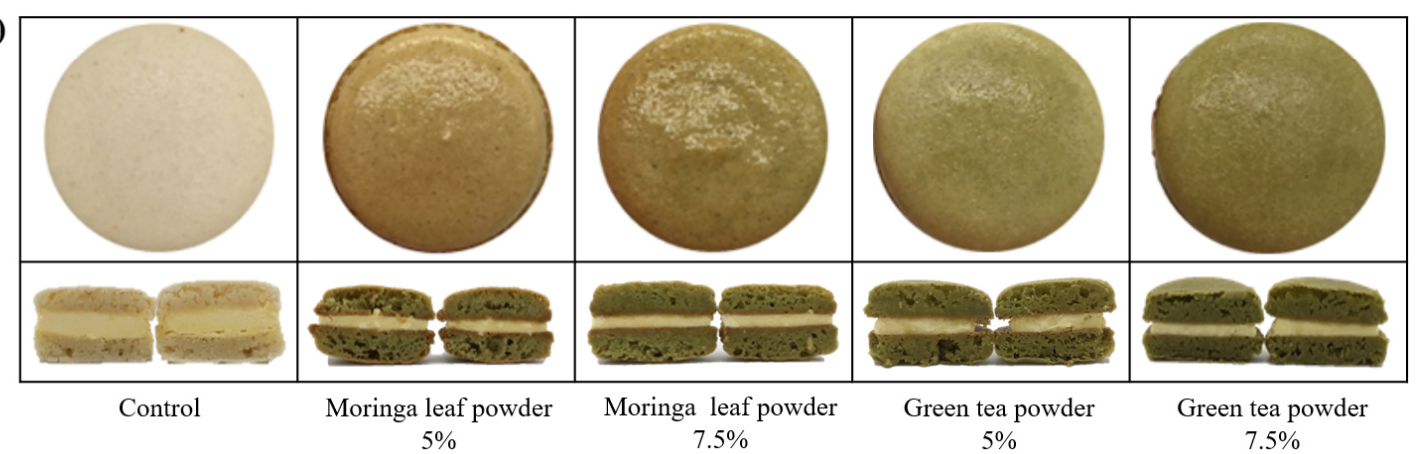

Fig. 1. Photographs of almond, moringa leaf and green tea powders (A), and macaroon added with moringa leaf and green tea powder (B).

2), 이는 분말 첨가 마카롱의 색도 측정 결과와는 다른 경향 을 보였다.

녹색도에 가장 큰 영향을 주는 chlorophyll은 녹차에는 $1.12-1.89 \mathrm{mg} / \mathrm{g}($ Ošt’ádalová 등, 2015), 또는 $1.70-5.92 \mathrm{mg} / \mathrm{g}$ (Lee 등, 2010), 모링가잎 분말에는 6.29-7.21 mg/g(Saini 등, 2014) 또는 2.33-5.32 mg/g(Wasonowati 등, 2019) 함유되어 있다. 식물체의 chlorophyll은 청록색인 chlorophyll a과 황록 색인 chlorophyll b가 약 3:1의 비율로 분포되며, 저장기간 동 안 광선 또는 공기에 노출되거나 열처리과정에서 매우 sen- sitive하고 불안정하여, olive brown 색을 띠는 pheophytin a 와 $b$ 로 decomposition되며, chlorophyll $b$ 가 chlorophyll $a$ 보 다 상대적으로 안정하다 $(\mathrm{Li}$ 등, 2018). 시중 판매되는 녹차의 chlorophyll $a$ 와 b의 비율은 다양하며, Lee 등 (2010)의 보고 에 의하면 총 16 개 녹차 중 3 개의 시료에서 chlorophyll a가 많고, 이외의 시료에서는 유사하거나 chlorophyll b가 많았으 며, $\mathrm{Li}$ 등(2018)은 중국산 녹차는 chlorophyll b가 a보다 많지 만, pheophytin a의 함량이 높아, chlorophyll a로부터 pheophytin a로의 전환이 일어났음을 보고하고 있다. 모링가 
분말에는 chlorophyll a(1.70-3.59 mg/g 또는 4.98-6.45mg/g) 가 chlorophyll b(0.61-1.73 mg/g 또는 $1.30-1.76 \mathrm{mg} / \mathrm{g})$ 보다 3 배 정도 높게 분포하고 있다(Saini 등, 2014; Wasonowati 등, 2019). 본 연구에서 모링가잎 분말이 녹차분말보다 강한 녹색을 띄었는데, 이는 모링가 분말이 녹차분말보다 상대적 으로 높은 total chlorophyll 또는 chlorophyll a를 함유하기 때문인 것으로 생각된다. 반면, 마카롱 반죽이 오븐에서 구워 지는 동안 모링가 첨가 마카롱이 녹차 첨가 마카롱에 비해 상대적으로 녹색도가 감소하였는데, 이는 제조과정에서 오븐 의 높은 온도에 의해 chlorophyll이 pheophytin으로 전환되 고, 이 전환률이 모링가 첨가 마카롱에서 높기 때문인 것으로 생각된다.

또한, 마카롱 반죽을 오븐에서 굽는 과정에서 주재료인 설 탕에 의한 caramelization과 환원당과 아미노화합물(단백질, 아 미노산, 펩타이드)에 의한 Maillard 반응에 의해 갈색도가 증가 되는데, 아미노산 중 Lysine(Lys), Glycine(Gly), Tyrptophan (Trp), Tyrosine(Tyr)의 순으로 갈변화에 영향을 미친다 (Ashoor과 Zent, 1984). 최근 연구 보고에 의하면 모링가분말 의 단백질함량 $(30.29 \%$, Moyo 등, 2011$)$ 이 녹차분말 $(15 \%$, Chacko 등, 2010)보다 2배 정도 많고, 모링가분말에 함유된 Gly(1.533\%), Lys(1.737\%), Try (2.650\%), Trp(0.486\%) 함 량이 (Moyo 등, 2011) 녹차 분말의 Lys(0.016-0.024\%), Gly (0.003-0.004\%), $\quad \operatorname{Thr}(0.015-0.028 \%), \quad \operatorname{Thy}(0.017-0.027 \%)$ ( $\mathrm{Su}$ 등, 2019) 함량보다 현저히 많아, 마카롱 제조시 높은 온 도의 오븐에서 모링가 첨가 마카롱의 갈변화가 더 많이 진행 되어 녹차 첨가 마카롱보다 황색과 적색도가 높고, 외관상으 로도 갈색이 강한 것으로 보인다.

\section{마카롱의 퍼짐성}

모링가 또는 녹차 분말을 아몬드분말 대비 각각 $5 \%$ 와 $7.5 \%$ 를 첨가한 마카롱의 퍼짐성 지수와 부피를 측정한 결과 를 Table 3 에 나타내었다, 분말 첨가군 $5 \%$ 의 퍼짐성은 대조 군 마카롱의 퍼짐성보다 유의적으로 크지만( $<<0.05)$, 분말
첨가량이 $7.5 \%$ 로 증가하면 퍼짐성은 감소하여 대조군과 유 의적인 차이는 없었다 $(\mathrm{p}>0.05)($ Table 3$)$. 분말 $5 \%$ 첨가군에 서는 모링가 마카롱의 퍼짐성지수가 녹차마카롱보다 유의적 으로 높지만( $\mathrm{p}<0.05), 7.5 \%$ 첨가군들에서는 유의적인 차이가 없었다( $\mathrm{p}>0.05)$. 퍼짐성은 오븐에서 반죽을 굽는 과정에서 반죽의 두께가 감소하고 직경이 커지는 현상으로, 유동성에 필요한 일정 점도를 상실할 때까지 일어난다(Doescher와 Hoseney, 1985; Finney 등, 1950). 퍼짐성은 반죽의 수분함량 과 관련성이 있으며, 반죽 내 수분의 함량이 높고 자유수로 존재하면 점도가 낮아 퍼짐성 지수가 높아지고, 수분함량이 낮고 결합수로 존재하면 점도가 높아 퍼짐성 지수는 낮아진 다(Kim, 2017; Miller 등, 1997). 또한, 퍼짐성은 반죽의 점도 에 의해 영향을 받으므로, 주재료 및 부재료의 배합비, 식이 섬유소 함량, 수분함량, 단백질 함량 등에 영향을 받을 수 있 다(Kim, 2017). 분말의 수분함량은 모링가 > 녹차 > 아몬드 분말의 순으로 유의적인 차이가 있고, 수분흡수 지수는 모링 가 분말이 녹차분말보다 높았다(Table 3). 모링가분말은 녹차 분말보다 단백질함량은 약 2 배 높고, 섬유소는 약 2 배 낮다고 보고되고 있다(Shokery 등, 2017). 분말의 수분함량과 단백 질 및 섬유소함량이 마카롱의 퍼짐성에 영향을 줄 수 있으며, 수분함량이 높으면 퍼짐성지수는 증가하여, $5 \%$ 첨가군에서 는 마카롱의 퍼짐성이 증가하지만, 그 이상으로 첨가하게 되 면, 분말에 함유된 섬유소와 단백질 함량도 증가하고 반죽의 수분흡수율이 증가되면서, 반죽 건조도가 높아지고 유동성에 필요한 일정 점도를 가지지 못하여 $5 \%$ 첨가군에 비해 퍼짐 성이 낮을 것으로 생각된다(Doescher와 Hoseney, 1985).

\section{마카롱의 텍스쳐와 부피}

Rheometer를 이용하여 마카롱의 텍스쳐를 측정한 결과, 분말 첨가 마카롱은 대조군보다 경도는 낮고 부서짐성과 응 집성은 높았다(Table 4). 모링가 분말의 첨가량이 증가하면 마카롱의 부서짐성과 경도는 유의적으로 감소하고 $(\mathrm{p}<0.05)$, 녹차분말 첨가 마카롱에서는 유의적인 차이는 없지만 첨가량

Table 3. Spread factor and volume of macaroon added with moringa leaf and green tea powder

\begin{tabular}{|c|c|c|c|c|c|c|c|c|c|}
\hline \multicolumn{6}{|c|}{ Macaroon } & \multicolumn{4}{|c|}{ Powder } \\
\hline & \multirow{2}{*}{ Control } & \multicolumn{2}{|c|}{ Moringa leaf } & \multicolumn{2}{|c|}{ Green tea } & & \multirow{2}{*}{ Almond } & \multirow{2}{*}{ Moringa leaf } & \multirow{2}{*}{ Green tea } \\
\hline & & $5 \%$ & $7.5 \%$ & $5 \%$ & $7.5 \%$ & & & & \\
\hline $\begin{array}{l}\text { Spread } \\
\text { factor }^{1)}\end{array}$ & $3.83 \pm 0.07^{\mathrm{c} 2)}$ & $4.59 \pm 0.18^{\mathrm{a}}$ & $3.77 \pm 0.07^{\mathrm{c}}$ & $4.06 \pm 0.09^{b}$ & $3.84 \pm 0.03^{\mathrm{c}}$ & $\begin{array}{l}\text { Water absorption } \\
\text { index (WAI) }\end{array}$ & -3) & $3.21 \pm 0.12^{\mathrm{a}}$ & $1.79 \pm 0.05^{\mathrm{b}}$ \\
\hline $\begin{array}{l}\text { Volume } \\
(\mathrm{mL})\end{array}$ & $27.77 \pm 0.96^{\mathrm{ab}}$ & $25.00 \pm 0.00^{\mathrm{c}}$ & $22.22 \pm 0.96^{\mathrm{d}}$ & $28.88 \pm 0.96^{\mathrm{a}}$ & $27.22 \pm 0.96^{\mathrm{b}}$ & $\begin{array}{c}\text { Moisture } \\
\text { content }(\%)\end{array}$ & $4.00 \pm 0.05^{\mathrm{c}}$ & $7.01 \pm 0.04^{\mathrm{a}}$ & $4.31 \pm 0.20^{\mathrm{b}}$ \\
\hline
\end{tabular}

${ }^{1)}$ Spread factor and volume was measured with macaroon coque.

${ }^{2)}$ Each value is mean $\pm \mathrm{SD}(\mathrm{n}=3)$, and values with different superscripts within the same row are significantly different at $\mathrm{p}<0.05$.

${ }^{3)}$, not available. 
Table 4. Texture properties of macaroon added with moringa leaf and green tea powder

\begin{tabular}{ccccccc}
\hline \multirow{2}{*}{ Macaroon } & \multirow{2}{*}{ Control } & \multicolumn{2}{c}{ Moringa leaf powder } & & \multicolumn{2}{c}{ Green tea powder } \\
\cline { 3 - 4 } & & $5 \%$ & $7.5 \%$ & $5 \%$ & $7.5 \%$ \\
\hline Hardness $\left(\mathrm{g} / \mathrm{cm}^{2}\right)$ & $6,662.20 \pm 530.70^{1) \mathrm{a} 2)}$ & $5,516.80 \pm 959.74^{\mathrm{b}}$ & $1,144.86 \pm 88.32^{\mathrm{c}}$ & & $881.08 \pm 81.70^{\mathrm{c}}$ & $927.81 \pm 55.85^{\mathrm{c}}$ \\
Fracturability $(\mathrm{g})$ & $420.87 \pm 167.33^{\mathrm{b}}$ & $8,692.96 \pm 2,103.05^{\mathrm{a}}$ & $1,800.85 \pm 247.00^{\mathrm{b}}$ & & $1,634.51 \pm 249.63^{\mathrm{b}}$ & $1,353.31 \pm 248.76^{\mathrm{b}}$ \\
Cohesiveness $(\%)$ & $2.42 \pm 0.59^{\mathrm{d}}$ & $20.68 \pm 5.74^{\mathrm{c}}$ & $22.22 \pm 1.20^{\mathrm{bc}}$ & & $27.26 \pm 1.66^{\mathrm{a}}$ & $26.00 \pm 2.84^{\mathrm{ab}}$ \\
\hline
\end{tabular}

${ }^{1)}$ Each value is mean $\pm \mathrm{SD}(\mathrm{n}=3)$.

${ }^{2)}$ Values with different superscripts within the same row are significantly different at $\mathrm{p}<0.05$.

이 많을수록 부서짐성은 낮고 경도는 증가하는 경향을 보였 다( $\mathrm{p}>0.05)$. 응집성은 분말첨가량 증가에 따른 유의적인 차 이는 없지만, 모링가 마카롱에서는 증가하고 녹차 마카롱에 서는 감소하는 경향을 보였다( $\mathrm{p}>0.05)$. 마카롱의 조직감은 첨가되는 부재료의 종류 및 첨가비율, 수분함량, 섬유소 함 량, 당 성분 등에 의해 영향을 받게 되는데(Kim, 2017), 녹차 와 모링가에 함유된 섬유소에 의해 마카롱 반죽 내의 수분 보유력이 증가하게 되고, 퍼짐성은 감소하지만, 경도는 낮아 지고 응집성은 증가하게 되어 관능검사의 결과와 유사하게 쫀득한 조직감의 특성을 가진 것으로 생각된다(Table 4). 특 히, 섬유소는 모링가에 비해 녹차에 많이 함유되어 있어, 상 대적으로 녹차마카롱이 응집성은 높지만 단단함은 줄어들고, 쫀득함의 특성이 증진된 것으로 보인다. 이는 Park 등(2018) 이 천연재료의 첨가에 의해 마카롱의 경도가 감소한다고 보 고한 연구결과와 유사하였다.

마카롱의 부피는 대조군과 비교할 때 녹차 첨가군들의 부 피는 유의적인 차이가 없지만 $(\mathrm{p}>0.05)$, 모링가 첨가군은 유 의적으로 작은 부피를 나타내었고 $(\mathrm{p}<0.05)$, 녹차와 모링가잎 분말의 첨가량이 증가할수록 감소하였다 $(\mathrm{p}<0.05)($ Table 3$)$. 동일한 분말 첨가량인 경우, 녹차 마카롱의 부피(27.22-28.88 $\mathrm{mL}$ )가 모링가 마카롱(22.22-25.00 mL)보다 유의적으로 컸다 $(\mathrm{p}<0.05)$. 마카롱은 기포의 팽창으로 제품의 비중을 얻는 거 품형 쿠키로서, 기포의 안정성은 반죽의 점성과 기포형성력 의 영향을 받는다고 알려져 있는데(Hong과 Lee, 2015; Kim, 2003), 수분흡수지수가 높은 모링가 분말 첨가군이 다른 군 들에 비해 기포 팽창에 필요한 수분 함량이 적어지면서 기포 포집력이 낮아져 마카롱 꼬끄의 부피의 팽창이 감소된 것으 로 생각된다.

\section{마카롱의 관능특성}

모링가와 녹차 분말을 첨가한 마카롱의 관능적 특성 강도 와 기호도 검사를 실시하였으며, 그 결과는 Table 5 와 같다. 마카롱의 녹색의 진한 정도는 분말 첨가량이 많을수록 강하 고, 모링가보다는 녹차분말을 첨가한 마카롱의 녹색이 강하
게 평가되어, 녹차 $7.5 \%$ 첨가 마카롱의 녹색의 강도가 유의 적으로 높은 6.09 의 강도 점수를 받았으며 $(\mathrm{p}<0.05)$, 이는 색 도 결과 값과 일치하였다(Table 3). 풋내와 풋맛의 강한 정도 는 녹차 $7.5 \%>$ 녹차 $5 \%>$ 모링가 $7.5 \%>$ 모링가 $5 \%>$ 대조군의 순으로, 녹차분말이 가진 특유의 풋내와 풋맛의 진 한 강도가 모링가보다는 강하여 제조된 마카롱에 이행된 것 으로 생각된다. 마카롱의 쫀득한 정도는 분말 첨가 마카롱에 서 강하였으며(모링가 $5 \%$ 제외), 동일한 첨가량에 대해 녹차 마카롱이 모링가마카롱보다 강하고, 그중 녹차 $7.5 \%$ 마카롱 의 쫀득한 정도가 가장 강하였으며 $(\mathrm{p}<0.05)$, 분말 첨가 마카롱 의 쫀득함의 정도는 퍼짐성지수가 낮을수록 강하게 나타났다.

마카롱의 기호도 검사 결과, 외관은 대조군 마카롱이 가장 높은 점수를 받은 반면, 분말 첨가군에서는 모링가 $7.5 \%$ 첨 가군이 가장 낮은 점수(4.38), 녹차 $7.5 \%$ 첨가군이 높은 점수 (5.17)를 받았다. 대조군 마카롱의 퍼짐성지수와 부피결과와 가장 유사한 마카롱인 녹차 $7.5 \%$ 군의 외관기호도가 높은 것 을 고려할 때 퍼짐성 정도와 부피가 마카롱 외관의 기호도에 큰 영향을 준 것으로 생각된다. 색상의 기호도는 대조군에서 가장 높고, 모링가 첨가군이 녹차 첨가군보다 높고, 분말 첨 가량이 증가할수록 감소하는 경향을 보였다. 대조군과 같이 밝고 하얀 색상이 마카롱의 기호도를 증가시킨 반면, 모링가 와 녹차분말 첨가로 인한 어둡고 강한 황색과 녹색은 상대적 으로 기호도를 감소시키는 것으로 보인다. 마카롱 향의 기호 도는 대조군에서 가장 높고, 녹차 첨가군이 모링가 첨가군보 다 높은 경향을, 맛은 녹차 첨가군에서 가장 높게 평가되어, 녹차분말의 풋내와 풋맛이 향과 맛의 기호도를 높인 것으로 생각된다. 조직감의 기호도는 녹차 $7.5 \%$ 첨가군이 가장 높 고, 다음으로 모링가 $7.5 \%$, 녹차 $5 \%$, 대조군, 모링가 $5 \%$ 의 순이었으며, 이는 모링가의 쫀득한 정도의 강도점수와 유사 한 순으로, 마카롱의 쫀득한 정도가 강할수록 조직감의 기호 도를 증진시키는 것으로 보인다. 전체적인 기호도는 분말 첨 가 마카롱(모링가 5\% 제외)이 대조군보다 높았으며, 향, 맛, 조직감의 기호도가 높은 녹차 첨가 마카롱의 전체적인 기호 도가 높았다. 
Table 5. Sensory evaluation of macaroon added with moringa leaf and green tea powder

\begin{tabular}{|c|c|c|c|c|c|c|}
\hline & & \multirow{2}{*}{ Control } & \multicolumn{2}{|c|}{ Moringa leaf powder } & \multicolumn{2}{|c|}{ Green tea powder } \\
\hline & & & $5 \%$ & $7.5 \%$ & $5 \%$ & $7.5 \%$ \\
\hline \multirow{7}{*}{$\begin{array}{c}\text { Sensory attribute } \\
\text { intensity }\end{array}$} & Greenish color & $1.04 \pm 0.20^{\mathrm{d} 1) 2)}$ & $3.45 \pm 0.95^{\mathrm{c}}$ & $4.85 \pm 0.83^{\mathrm{b}}$ & $4.98 \pm 0.97^{\mathrm{b}}$ & $6.09 \pm 0.95^{\mathrm{a}}$ \\
\hline & Grass smell & $1.43 \pm 0.85^{\mathrm{d}}$ & $3.77 \pm 1.39^{\mathrm{c}}$ & $4.49 \pm 1.52^{\mathrm{b}}$ & $4.62 \pm 1.41^{\mathrm{b}}$ & $5.19 \pm 1.30^{\mathrm{a}}$ \\
\hline & Green taste & $1.34 \pm 0.84^{\mathrm{d}}$ & $3.91 \pm 1.57^{\mathrm{c}}$ & $4.11 \pm 1.37^{\mathrm{c}}$ & $4.66 \pm 1.32^{b}$ & $5.70 \pm 1.27^{\mathrm{a}}$ \\
\hline & Sweetness & $4.85 \pm 1.37^{\mathrm{a}}$ & $3.87 \pm 1.44^{\mathrm{b}}$ & $3.89 \pm 1.06^{\mathrm{b}}$ & $3.89 \pm 1.31^{\mathrm{b}}$ & $4.00 \pm 1.27^{\mathrm{b}}$ \\
\hline & Chewiness & $3.47 \pm 1.25^{\mathrm{c}}$ & $2.23 \pm 1.09^{\mathrm{d}}$ & $5.68 \pm 1.09^{\mathrm{b}}$ & $5.30 \pm 1.38^{\mathrm{b}}$ & $6.26 \pm 0.82^{\mathrm{a}}$ \\
\hline & & & \multicolumn{2}{|c|}{ Moringa leaf powder } & \multicolumn{2}{|c|}{ Green tea powder } \\
\hline & & 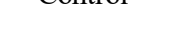 & $5 \%$ & $7.5 \%$ & $5 \%$ & $7.5 \%$ \\
\hline \multirow{6}{*}{$\begin{array}{c}\text { Sensory } \\
\text { acceptability }\end{array}$} & Appearance & $5.38 \pm 1.24^{\mathrm{a}}$ & $5.07 \pm 1.07^{\mathrm{a}}$ & $4.38 \pm 1.24^{\mathrm{b}}$ & $4.72 \pm 1.16^{\mathrm{ab}}$ & $5.17 \pm 1.28^{\mathrm{a}}$ \\
\hline & Color & $4.98 \pm 1.33^{\mathrm{a}}$ & $4.80 \pm 1.38^{\mathrm{ab}}$ & $4.41 \pm 1.38^{\mathrm{abc}}$ & $4.34 \pm 1.06^{\mathrm{bc}}$ & $3.95 \pm 1.36^{\mathrm{c}}$ \\
\hline & Aroma & $4.75 \pm 1.40^{\mathrm{a}}$ & $4.16 \pm 1.16^{\mathrm{a}}$ & $4.18 \pm 1.59^{\mathrm{a}}$ & $4.45 \pm 1.23^{\mathrm{a}}$ & $4.57 \pm 1.30^{\mathrm{a}}$ \\
\hline & Taste & $4.61 \pm 1.15^{\mathrm{a}}$ & $4.42 \pm 1.57^{\mathrm{a}}$ & $4.61 \pm 1.37^{\mathrm{a}}$ & $4.82 \pm 1.27^{\mathrm{a}}$ & $4.97 \pm 1.26^{\mathrm{a}}$ \\
\hline & Texture & $4.44 \pm 1.19^{b}$ & $3.65 \pm 1.07^{\mathrm{c}}$ & $5.35 \pm 1.18^{\mathrm{a}}$ & $5.03 \pm 1.17^{\mathrm{a}}$ & $5.53 \pm 1.28^{\mathrm{a}}$ \\
\hline & Overall acceptability & $4.75 \pm 1.30^{\mathrm{ab}}$ & $4.15 \pm 1.41^{\mathrm{b}}$ & $5.00 \pm 1.38^{\mathrm{a}}$ & $5.18 \pm 1.22^{\mathrm{a}}$ & $5.10 \pm 1.53^{\mathrm{a}}$ \\
\hline
\end{tabular}

${ }^{1)}$ Values are expressed as the mean \pm SD using 7-point hedonic scale (1=extremely weak or dislike, $4=$ normal, $7=$ extremely strong or like).

${ }^{2)}$ Values with different superscripts within the same row are significantly different at $\mathrm{p}<0.05$.

\section{마카롱의 총페놀 및 총플라보노이드 함량}

모링가와 녹차 분말 첨가량을 달리하여 제조한 마카롱의 총페놀 및 총플라보노이드 함량은 Table 6과 같다. 총페놀 함 량은 녹차 $7.5 \%>$ 녹차 $5 \%>$ 모링가 $7.5 \%>$ 모링가 $5 \%$ $>$ 대조군 마카롱의 순으로 유의적으로 높았으며 $(\mathrm{p}<0.05)$, 녹 차 마카롱이 모링가 마카롱보다 2.01배(5\% 첨가)-3.11배 (7.5\% 첨가) 높고, 분말 첨가량이 증가할수록 유의적으로 증 가하였다 $(\mathrm{p}<0.05)$. 총플라보노이드 함량 또한 녹차 마카롱 (2.72-4.05 mg QE/g)이 모링가 마카롱(1.79-2.45mg QE/g)보
다 높았으며, 분말 첨가량이 증가할수록 유의적으로 증가하였 다 $(\mathrm{p}<0.05)$. Nadiah 등(2017)에 의하면 녹차의 총페놀과 총플 라보노이드 함량은 각각 136.51-231.23 mg GAE/g와 27.57$61.67 \mathrm{mg}$ catechin equivalent $/ \mathrm{g}$ 이고, 녹차의 polyphenol은 flavanol, flavandiol 등의 flavonoid와 phenolic acid으로 구성 되며, flavanol인 catechin은 total phenol content(TPC)의 약 $74.45 \%$ 를 차지한다. 반면, 모링가잎의 총페놀 함량은 36.02 $45.81 \mathrm{mg} \mathrm{GAE} / \mathrm{g}$ 이고, quercetin과 kaempferol을 포함하는 flavonoid 함량은 15-27 mg QE/g으로 보고되고 있다(Sreelatha

Table 6. Total phenolic and flavonoid contents, and antioxidant activities of macaroon added with moringa leaf and green tea powder

\begin{tabular}{|c|c|c|c|c|c|}
\hline \multirow{2}{*}{ Macaroon } & \multirow{2}{*}{ Control } & \multicolumn{2}{|c|}{ Moringa leaf powder } & \multicolumn{2}{|c|}{ Green tea powder } \\
\hline & & $5 \%$ & $7.5 \%$ & $5 \%$ & $7.5 \%$ \\
\hline TPC (mg GAE $/ \mathrm{g})$ & $0.29 \pm 0.01^{\mathrm{e} 4)}$ & $0.75 \pm 0.05^{\mathrm{d}}$ & $1.01 \pm 0.01^{\mathrm{c}}$ & $2.01 \pm 0.02^{\mathrm{b}}$ & $3.11 \pm 0.14^{\mathrm{a}}$ \\
\hline $\mathrm{TFC}\left(\mathrm{mg} \mathrm{QE} \mathrm{Q}^{2} / \mathrm{g}\right)$ & $0.36 \pm 0.09^{d}$ & $1.79 \pm 0.14^{\mathrm{c}}$ & $2.54 \pm 0.15^{\mathrm{b}}$ & $2.72 \pm 0.24^{\mathrm{b}}$ & $4.05 \pm 0.10^{\mathrm{a}}$ \\
\hline DPPH RSC (\%) & $5.10 \pm 0.44^{\mathrm{e}}$ & $76.73 \pm 1.48^{\mathrm{d}}$ & $78.11 \pm 0.26^{\mathrm{c}}$ & $80.56 \pm 0.69^{b}$ & $82.14 \pm 0.20^{\mathrm{a}}$ \\
\hline FRAP $\left(\mathrm{mg} \mathrm{AAE} \mathrm{AE}^{3)} / \mathrm{g}\right)$ & $0.15 \pm 0.07^{\mathrm{d}}$ & $0.54 \pm 0.12^{\mathrm{c}}$ & $0.69 \pm 0.10^{\mathrm{c}}$ & $3.48 \pm 0.10^{\mathrm{b}}$ & $4.20 \pm 0.22^{\mathrm{a}}$ \\
\hline
\end{tabular}

${ }^{1)} \mathrm{GAE}$, gallic acid equivalent.

${ }^{2)} \mathrm{QE}$, quercetin equivalent.

${ }^{3)} \mathrm{AAE}$, ascorbic acid equivalent.

${ }^{4)}$ Each value is mean $\pm \mathrm{SD}(\mathrm{n}=4)$, and values with different superscripts within the same row are significantly different at $\mathrm{p}<0.05$. 
와 Padma, 2009). 따라서, 녹차가 모링가잎보다 많은 polyphenol과 flavonoid를 함유하므로, 모링가잎보다는 녹차를 첨가한 마카롱에서 총페놀 및 총플라보노이드 함량이 높고, 분말 첨가량이 증가할수록 더 높았다.

\section{마카롱의 항산화 활성}

모링가 또는 녹차 분말을 첨가한 마카롱의 항산화 활성은 DPPH RSC와 FRAP value를 측정하여 비교하였다(Table 6). $\mathrm{DPPH}$ assay는 free radical이 시료의 항산화 물질에 의해 환 원되어 radical이 감소되는 정도를 측정하여 시료의 항산화 활성을 평가하며(Blois, 1958), FRAP assay는 산성의 환경에 서 ferric tripyridyltriazine( $\left.\mathrm{Fe}^{3+}-\mathrm{TPTZ}\right)$ 복합체가 ferrous tripyridyltriazine( $\mathrm{Fe}^{2+}-\mathrm{TPTZ}$ )로 환원되어 짙은 청색이 되는 원리로 항산화능을 측정한다(Benzie와 strain, 1996). 마카롱 의 DPPH radical 소거능은 녹차 $7.5 \%>$ 녹차 $5 \%>$ 모링가 $7.5 \%>$ 모링가 $5 \%>$ 대조군의 순으로 유의적으로 높고 $(\mathrm{p}<0.05)$, 녹차 첨가군(80.56-82.14\%)이 모링가 첨가군 (76.73-78.11\%)보다 유의적으로 높았으며 $(\mathrm{p}<0.05)$, 분말 첨 가량이 증가할수록 유의적으로 증가하였다 $(\mathrm{p}<0.05) . \mathrm{FRAP}$ value는 녹차 $7.5 \%>$ 녹차 $5 \%>$ 모링가 $7.5 \%$, 모링가 $5 \%$ $>$ 대조군 마카롱의 순으로 $(\mathrm{p}<0.05)$, 녹차와 모링가 분말 첨가 량이 증가할수록 FRAP vlaue가 높은 경향은 보였고, 녹차 첨 가 마카롱의 FRAP value(3.48-4.20 mg AAE/g)가 모링가 첨 가 마카롱(0.54-0.69 mg AAE $/ \mathrm{g})$ 보다 유의적으로 높게 나타 났다.

녹차에는 다양한 종류의 polyphenol과 flavonoid가 함유되 어 있어 녹차의 항산화능은 높다고 알려져 있으며, 특히 녹차 의 catechin은 구조상 3 개 이상의 수산화기를 가지며 전자 공 여를 통해 항산화 활성을 증가시킨다(Jaiswal과 Naik, 2017; Nadiah 등, 2015). 모링가잎의 phenolic compound는 대부분 quercetin과 kaempferol로 존재하며, electron donor로써 활성 산소를 보다 안정적인 화합물로 전환시켜 급진적 연쇄반응을 종식시킴으로써 항산화 활성 증가에 기여한다고 보고되고 있
다(Siddhuraju와 Becker, 2003). 따라서 항산화 물질인 polyphenol과 flavonoid 함량이 높은 녹차가 첨가된 마카롱이 모 링가 첨가 마카롱보다 DPPH RSC 및 FRAP value가 높고, 분말 첨가량에 비례하여 DPPH radical 소거능과 FRAP value 가 증가된 것으로 보인다(Nadiah 등, 2015; Sreelatha와 Padma, 2009). Choi(2018)는 모링가잎 분말을 첨가하여 쿠키를 제조 하면 총페놀 함량 및 DPPH radical 소거능이 증가한다고 하 였고, Lee와 Hwang(2016)은 쌀스펀지 케이크의 제조에서 녹 차 분말의 첨가량이 증가할수록 총폴리페놀 및 총플라보노이 드 함량, DPPH radical 소거능도 증가한다고 하였다.

마카롱의 총페놀(TPC) 및 총플라보노이드 함량(TFC)과 $\mathrm{DPPH} \mathrm{RSC}$ 와 FRAP value의 상관관계를 분석한 결과, 마카 롱의 TPC는 TFC, DPPH RSC와 FRAP value와 서로 양의 상관관계를 가지고 있다(Table 7). TFC와 DPPH RSC, TFC 와 FRAP value의 roㅡㄴ 각각 0.919 와 0.963 으로 이들 간에는 강한 양의 상관관계를 나타내었으며, TPC와 이들의 상관관 계 $\mathrm{r}$ 인 0.827 과 0.546 보다 높은 값을 가지므로, $\mathrm{TFC}$ 가 TPC 보다 마카롱의 항산화 활성 증가에 상대적으로 높게 기여함 이 확인되었다.

\section{요 약}

아몬드가루 대비 모링가잎과 녹차 분말 $5 \%$ 와 $7.5 \%$ 첨가 한 마카롱을 제조하고, 품질과 관능적 특성 및 항산화 활성을 평가하였다. 모링가 첨가 마카롱은 강한 황적색을, 녹차 첨가 마카롱은 강한 녹색을 띄었다. 마카롱의 퍼짐성은 분말 첨가 군에서 증가하여 모링가 $5 \%$ 첨가 마카롱이 가장 높고, 첨가 량이 증가하면 감소하는 경향을 보였다. 마카롱의 부피는 녹 차 마카롱과 대조군은 유사한 반면 모링가 마카롱은 감소하 였다. 대조군과 비교하여 분말 첨가 마카롱의 응집성과 부서 짐성은 증가하고 경도는 감소하였고, 분말첨가량이 많을수록 부서짐성은 감소하는 경향을 보였다. 총페놀 함량은 분말 첨 가 마카롱이 대조군보다 유의적으로 높고( $\mathrm{p}<0.05)$, 녹차 마

Table 7. Pearson's correlation matrix between the contents of total phenolic and flavonoid, and antioxidant activities

\begin{tabular}{ccccc}
\hline & TPC & TFC & DPPH RSC & FRAP value \\
\hline TPC & $\mathrm{r}=1$ & - & - \\
TFC & $\mathrm{r}=0.614^{* * 2)}$ & & - \\
& $(\mathrm{p}=0.004)$ & $\mathrm{r}=1$ & & \\
DPPH RSC & $\mathrm{r}=0.827^{* *}$ & $\mathrm{r}=0.919^{* *}$ & \\
& $(\mathrm{p}=0.000)$ & $(\mathrm{p}=0.000)$ & $\mathrm{r}=1$ & - \\
FRAP value & $\mathrm{r}=0.546^{*}$ & $\mathrm{r}=0.962^{* *}$ & \\
& $(\mathrm{p}=0.013)$ & $(\mathrm{p}=0.000)$ & $\mathrm{r}=0.030^{* *}$ & $\mathrm{r}=1$ \\
\hline
\end{tabular}

${ }^{1)}$ TPC, total phenolic content; TFC, total flavonoids content; DPPH, free radical scavenging capacity; FRAP, ferric reducing antioxidant power.

${ }^{2)}{ }^{*}$ correlation is significant at $\mathrm{p}<0.05,{ }^{* *}$ correlation is significant at $\mathrm{p}<0.01$. 
카롱이 모링가 마카롱보다 2.01배(5\% 첨가)-3.11배(7.5\% 첨 가) 높고, 분말 첨가량이 증가할수록 유의적으로 증가하였다 $(\mathrm{p}<0.05)$. 총플라보노이드 함량은 녹차 마카롱 $(2.72-4.05 \mathrm{mg}$ $\mathrm{QE} / \mathrm{g})$ 이 모링가 마카롱(1.79-2.45 mg QE/g)보다 높았으며, 분말 첨가량이 증가할수록 유의적으로 증가하였다 $(\mathrm{p}<0.05)$. $\mathrm{DPPH}$ radical 소거능은 녹차 마카롱(80.56-82.14\%)이 모링 가 마카롱(76.73-78.11\%)보다 높고( $\mathrm{p}<0.05)$, FRAP value는 녹차 마카롱(3.48-4.20 mg AAE/g)이 모링가 마카롱(0.54-0.69 $\mathrm{mg} \mathrm{AAE} / \mathrm{g})$ 보다 높았으며 $(\mathrm{p}<0.05)$, 분말 첨가량이 증가할수 록 유의적으로 증가하였다 $(\mathrm{p}<0.05)$. 마카롱의 녹색, 풋내, 풋 맛, 쫀득한 조직감의 특성 강도는 녹차 마카롱이 높고, 첨가 량이 많을수록 강도는 증가하는 경향을 보였다. 외관, 색상과 향의 기호도는 대조군 마카롱이 가장 높고, 분말 첨가 마카롱 에서는 외관은 모링가 첨가, 향은 녹차 첨가 마카롱을 선호하 는 경향을 보였다. 맛과 조직감의 기호도는 녹차마카롱이 높 고, 분말 첨가량이 증가할수록 높은 점수를 받았으며, 전체적 인 기호도는 녹차 마카롱이 모링가 마카롱보다 높았다. 모링 가잎 또는 녹차 분말이 첨가된 마카롱은 쫀득한 조직감과 특 유의 향과 맛을 지니며, 페놀화합물과 플라보노이드의 함량 이 높아 항산화 활성도가 높은 기능성이 우수하며, 특히 모링 가보다는 녹차가 첨가한 마카롱이 맛, 향, 조직감과 전체적인 기호도가 우수하고, 항산화력이 높은 기능성 디저트 베이커 리 제품으로서의 제품화가 높을 것으로 생각된다.

\section{감사의 글}

본 연구는 2018년도 대구대학교 학술연구비 지원에 의해 이루어진 결과로 이에 감사드립니다.

\section{Conflict of interests}

The authors declare no potential conflict of interest.

\section{ORICD}

Chae Wan Baek https://orcid.org/0000-0001-6810-2570 Jeung Hee Lee https://orcid.org/0000-0002-4224-771X

\section{References}

AACC. Approved Methods of AACC. 10th ed, American Association of Cereal Chemists, St Paul, MN, USA, Method 10-50D (1983)

Abdel-hameed ESS. Total phenolic contents and free radical scavenging activity of certain Egyptian Ficus species leaf samples. Food Chem, 114, 1271-1277 (2009)

AOAC. Official Methods of Analysis. 16th ed, Association of Official Analytical Chemists, Washington DC, USA, p 788 (1990)

Ashoor SH, Zent JB. Maillard browning of common amino acids and sugars. J Food Sci, 49, 1206-1207 (1984)

AT food information statistics system. https://www.atfis.or. $\mathrm{kr} /$ article/M001010000/view.do?articleId=2608\&boardId $=2$ \&page $=\&$ searchKey $=\&$ searchString $=\&$ searchCategory $=($ accessed April 2020)

Baek EY, Jeong WY. Determinants of health oriented consumption. J Consum Cult, 9, 25-47 (2006)

Benzie IFF, Strain JJ. The ferric reducing ability of plasma (FRAP) as a measure of "antioxidant power": The FRAP assay. Anal Biochem, 239, 70-79 (1996)

Blois MS. Antioxidant determinations by the use of a stable free radical. Nature, 181, 1199-1200 (1958)

Chacko SM, Thambi PT, Kuttan R, Nishigaki I. Beneficial effects of green tea: A literature review. Chin Med, 5, 13 (2010)

Choi SH. Quality characteristics and antioxidant activity of cookies added with moringa (Moringa oleifera Lam.) leaf powder. Culi Sci Hos Res, 24, 102-111 (2018)

Doescher LC, Hoseney RC. Effect of sugar type and flour moisture on surface cracking of sugar-snap cookies. Cereal Chem, 62, 263-266 (1985)

Finney KF, Morris VH, Yamazaki WT. Micro versus macro cookies baking procedures for evaluation the cookie quality of wheat varieties. Cereal Chem, 27, $42-49$ (1950)

Folin O, Denis W. On phosphotungstic-phosphomolybdic compounds as color reagents. J Biol Chem, 12, 239-243 (1912)

Hong YJ, Lee YS. Quality characteristics of cookies prepared with Chinese sweet tea leaf (Rubus suavissimus $\mathrm{S}$. Lee) powder. Korean J Culinary Res, 21, 182-194 (2015)

Im JG, Kim YH. Effect of green tea addition on the quality of white bread. Korea J Soc Food Sci, 15, 395-400 (1999)

Jaiswal SG, Naik S. Pressurized liquid extraction of antioxidant compounds from green tea. Am J Food Technol, 12, 358-366 (2017)

Jung KI. Quality characteristics of muffins added with moringa (Moringa oleifera Lam.) leaf powder. J Korean 
Soc Food Sci Nutr, 45, 872-879 (2016)

Kim KJ. Quality characteristics and antioxidant activities of macaron with cabbage powder. Food Eng Prog, 21, 367-374 (2017)

Kim YA. Effect of mulberry leaves powders on the quality characteristics of yellow layer cakes. Korean J Food Sci Technol, 35, 871-876 (2003)

Korea consumer agency. https://www.kca.go.kr/kca/sub.do? menukey $=5084 \&$ mode $=$ view $\&$ no $=1002803070 \quad$ (accessed April 2020)

Kumar Gupta S, Kumar B, Srinivasan BP, Nag TC, Srivastava S, Saxena R, Aggarwal A. Retinoprotective effects of Moringa oleifera via antioxidant, anti-inflammatory, and anti-angiogenic mechanisms in streptozotocininduced diabetic rats. J Ocul Pharmacol Th, 29, 419-426 (2013)

Lee LS, Park JD, Cha HS, Lee YM, Park JW, Kim SH. Physicochemical properties of powdered green teas in Korea. Korean J Food Sci Technol, 42, 33-38 (2010)

Lee MJ, Hwang ES. Quality characteristic and antioxidant of rice sponge cake with added green tea powder. Korean J Food Sci Technol, 48, 354-360 (2016)

Li X, Zhou R, Xu K, Xu J, Jin J, Fang H, He Y. Rapid determination of chlorophyll and pheophytin in green tea using fourier transform infrared spectroscopy. Molecules, 23, 1010 (2018)

Miller RA, Hoseney RC, Morris CF. Effect of formula water content in the spread of sugar-snap cookies. Cereal Chem, 74, 669-671 (1997)

Moyo B, Masika PJ, Hugo A, Muchenje V. Nutritional characterization of moringa (Moringa oleifera Lam.) leaves. Afr J Biotechnol, 10, 12925-12933 (2011)

Muramatsu K, Fukuyo M, Hara Y. Effect of green tea catechins on plasma cholesterol level in cholesterol-fed rats. J Nutr Sci Vitaminol, 32, 613-622 (1986)

Nadiah NI, Cheng LH, Azhar ME, Karim AA, Uthumporn U, Ruri AS. Determination of phenolics and antioxidant properties in tea and the effects of polyphenols on alpha-amylase activity. Pakistan J Nutr, 14, 808-817 (2015)

Oštádalová M, Tremlová B, Pokorná J, Král M. Chlorophyll as an indicator of green tea quality. Acta Vet Brno, 83, 103-109 (2014)

Park GS, Lee SJ. Effects of job's tears powder and green tea powder on the characteristics of quality of bread. J
Korean Soc Food Sci Nutr, 28, 1244-1250 (1999)

Park OJ, Park MH, Lee SH, Lee SM. Characteristics of macaroons prepared with natural materials and artificial food colorant. Korean J Food Nutr, 31, 631-639 (2018)

Ramachandran C, Peter KV, Gopalakrishnan PK. Drumstick (Moringa oleifera): A multipurpose Indian vegetable. Econ Bot, 34, 276-283 (1980)

Saini RK, Shetty NP, Prakash M, Giridhar P. Effect of dehydration methods on retention of carotenoids, tocopherols, ascorbic acid and antioxidant activity in Moringa oleifera leaves and preparation of a RTE product. J Food Sci Technol, 51, 2176-2182 (2014)

Shokery ES, El-Ziney MG, Yossef AH, Mashaly RI. Effect of green tea and moringa leave extracts fortification on the physicochemical, rheological, sensory and antioxidant properties of set-type yoghurt. J Adv Dairy Res, 5, 1-10 (2017)

Siddhuraju P, Becker K. Antioxidant properties of various solvent extracts of total phenolic constituents from three different agroclimatic origins of drumstick tree (Moringa oleifera Lam.) leaves. J Agric Food Chem, 51, 21442155 (2003)

Singh Y, Prasad K. Moringa oleifera leaf as functional food powder: characterization and uses. Int $\mathrm{J}$ Food Sci Technol, 4, 317-324 (2013)

Sreelatha S, Padma PR. Antioxidant activity and total phenolic content of Moringa oleifera leaves in two stages of maturity. Plant Foods Hum Nutr, 64, 303-311 (2009)

$\mathrm{Su} \mathrm{H}, \mathrm{Wu} \mathrm{W}$, Wan X, Ning J. Discriminating geographical origins of green tea based on amino acid, polyphenol, and caffeine content through high-performance liquid chromatography: Taking Lu'an guapian tea as an example. Food Sci Nutr, 7, 2167-2175 (2019)

Wasonowati C, Sulistyaningsih E, Indradewa D, Kurniasih B. Physiological characters of Moringa oleifera Lamk in Madura. AIP Conf Proc, 2120, 030024-1-030024-6 (2019)

Yu GB, Ahn DK. A study on consumers' perceived value and emotion from dessert consumption experience: Focusing on the dessert consumption measurement development and its implications. J Foodservice Management Soc Korea, 21, 7-27 (2018)

Yu GH, Lee YJ, Choe JW, Hong DK. Ratio of price to satisfaction marketing. Marketing, 52, 65-70 (2018) 